\title{
Seasonal variation in phytomass and nutrient status of Phragmites australis along the water courses in the middle Nile Delta, Egypt.
}

\author{
Hassan Fared El-Kady \\ Botany Department, Faculty of Science, Tanta University, \\ Tanta, Egypt.
}

El-Kady H. F. 2000. Seasonal variation in phytomass and nutrient status of Phragmites australis along the water courses in the middle Nile Delta, Egypt. Taeckholmia 20(2): 123-138.

\begin{abstract}
The present study provides an evaluation of the nutrient status of Phragmites australis, which is one of the most important weeds along the water courses in the middle Nile Delta Egypt. Shoots were collected seasonally from twenty-five permanent stands. Living and dead parts and total phytomass were estimated. The inorganic (Na, K, $\mathrm{Ca}, \mathrm{Fe}, \mathrm{Mg}, \mathrm{P}, \mathrm{Cu}, \mathrm{Mn}, \mathrm{Zn}, \mathrm{Pb}$ and $\mathrm{Co}$ ) and organic (carbohydrates, total nitrogen, total protein, ether extract, crude fiber and ash) contents were estimated. Some digestible and energy parameters (digestible protein, total digestible nutrient, digestible energy, metaboilse energy, and net energy) were calculated. Based on the nutrient analysis, the present study evaluated the nutritive value of plant as a poor forage.
\end{abstract}

Key words: Phragmites australis, water courses, Nile Delta, phytomass, nutritive value.

\section{Introduction}

Phragmites australis (Cav.) Trin. ex. Steud., is believed by many authors to be the most widely distributed of all angiosperms (Holm et al.1977). It occurs in flood plains, tidal marshes, ditches, and other low-lying, poorly drained areas over much of the world (Riemer 1976). Although a native of the Old World tropics, it is remarkable for being equally at home in the countries of the northern temperate zone and in the torrid swamps of the Nile. It is important in many shallow lakes and wetlands in the boreal and tropical parts of the world, and occurs in mesotrophic, oligotrophic and some eutrophic reed swamps (Chapman 1960). Phragmites australis is widespread in Egypt, where it occurs in water and wetlands of all phytogeographical territories (Täckholm 1974; Zahran \& Willis 1992; Boulos 1995). It is quite remarkable for its strong, tall, aerial culms and leaves and its extensive creeping rhizome system with abundant lateral branching (Sculthorpe 1967). It should not be surprising that a weed which is so widespread has had a fascinating role in the life of man as he sought to make a home, feed his animals, prepare articles for commerce, and to use it (or against it) in his irrigation schemes and agricultural fields (Holm et al.1977). Because of the fact that Phragmites australis can propagate both vegetatively and by means of seed, it is so useful for soil conservation and for the stabilization of sediment, gully banks and channels (Viljoen 1976). The vegetative parts of Phragmites australis provide shade, shelter, and food for fish and the seeds provide food for ducks. These parts are eaten by cattle, goats and sheep, and are very important food for muskrats and for pigs in some areas (Holm et al. 1977). It was an important source of matting in ancient Egypt and is widely used for that purpose today. It is important in the horticultural trade for mats, shading, and containers in the Netherlands. It is plaited into sandals; the culms are carved into writing pens; it makes excellent thatch; and is an important raw material in papermaking.

Received 21 February 2000. Revision accepted 13 October 2000 
Recently, international attention has been directed towards the capacity of constructed reed wetlands to control water pollution and to treat municipal and industrial wastewater (Gersberg et al. 1986; May et al. 1990; Williams et al. 1994). Phragmites australis is an ideal candidate because it can form deep roots and hollow rhizomes supporting a great volume of active rhizosphere. Leakage of oxygen from the roots may create oxidized micro-zones that remove organics and suspended solids as well as nitrogen and phosphorus from waste water (Brix \& Schierup 1989). The potential for resource recovery by harvesting and utilizing the biomass produced as an energy source, as compost or fodder should be emphasized Anonymous (1976). In Sweden, Granéli (1980) used Phragmites australis as an energy source.

The study carried out by Shaltout \& El-Sheikh (1993) indicated that Phragmites australis is a very common species along the canal banks of middle Delta and has a presence percentage about $88 \%$. The aim of the present study is to estimate the phytomass and to evaluate the nutritive value of Phragmites australis (Cav.) Trin. Ex. Steud. in terms of estimating its organic and inorganic chemical compositions. This study may assist in understanding the importance of this plant in animal nutrition in Egypt.

\section{Study area}

The area of the present study is a part of the Nile Delta region of Egypt (Fig. 1). It is represented by five localities in El-Gharbia (Tanta, Samannoud and Kafr El-Zyat), Kafr El-Sheikh (Sakha) and El-Menofia (Berket El-Saba) Governerates. As indicated by Abu Al-Izz (1971), there were seven branches of the Nile from East to West. The elimination of some of these distributaries may have been due to variation in elevation of the Deltaic debris. Geologically, the area of Nile Delta had been subjected to the same geologic events that affected northern Egypt during the pre-Miocene geologic history. The Delta is bounded on the eastern side by a major upward zone, which occupies most of north central Sinai. This zone extends westwards into "Cairo-Suez Anticlinal Horst" (Shata \& Fayoumi 1970) and is followed, northwards, by a major downward zone which occupies most of the Delta and its extension into northwest Sinai.

Because the thousands of years of agricultural activity, all soils with exception of the northern most part, are man made and are regarded as anthropic variants of the Gleysols and Fluvisols. The low layer Delta is flat separated from the open sea by a narrow belt of Silic semistatic (and partly dynamic) Ergosols. This sand dune bar grows in the littoral of the shallow sea and gradually separates closed lagoons, which consequently turn into salty lakes and then with the gradual silting into Marshy Solonchaks. Again we have here the process of gradual silting, uplifting and consequent desalinization. All stages of this process may be observed in the northern part of the Delta. In the eastern and western parts of the Delta, where the deposits are not so heavy and sandy, bars are numerous, and the desalinization of salt marshes leads to the Saluki Gleysols and then Humic Gleysols. But in the middle Delta, which is composed of very fine textured materials, the Solonetzs form a stage of desalinization after the Solonchak stage (ElGabaly et al. 1969).

According to the map of the world distribution of arid regions (UNESCO 1977). The northern part of the Nile Delta lies in arid region, and the southern part lies in hyperarid region. The climatic conditions are warm summer $\left(20\right.$ to $\left.30^{\circ} \mathrm{C}\right)$ and mild winter (10 to $20^{\circ} \mathrm{C}$ ). Though occasional short rainstorms occur in winter, most days are sunny. 
The aridity index (P/ETP) is between 0.03 and 0.2 at the North Delta (arid region) and less than 0.30 at its south (hyperarid region); where $\mathrm{P}$ is annual precipitation and $\mathrm{E}$ is annual evaporation.

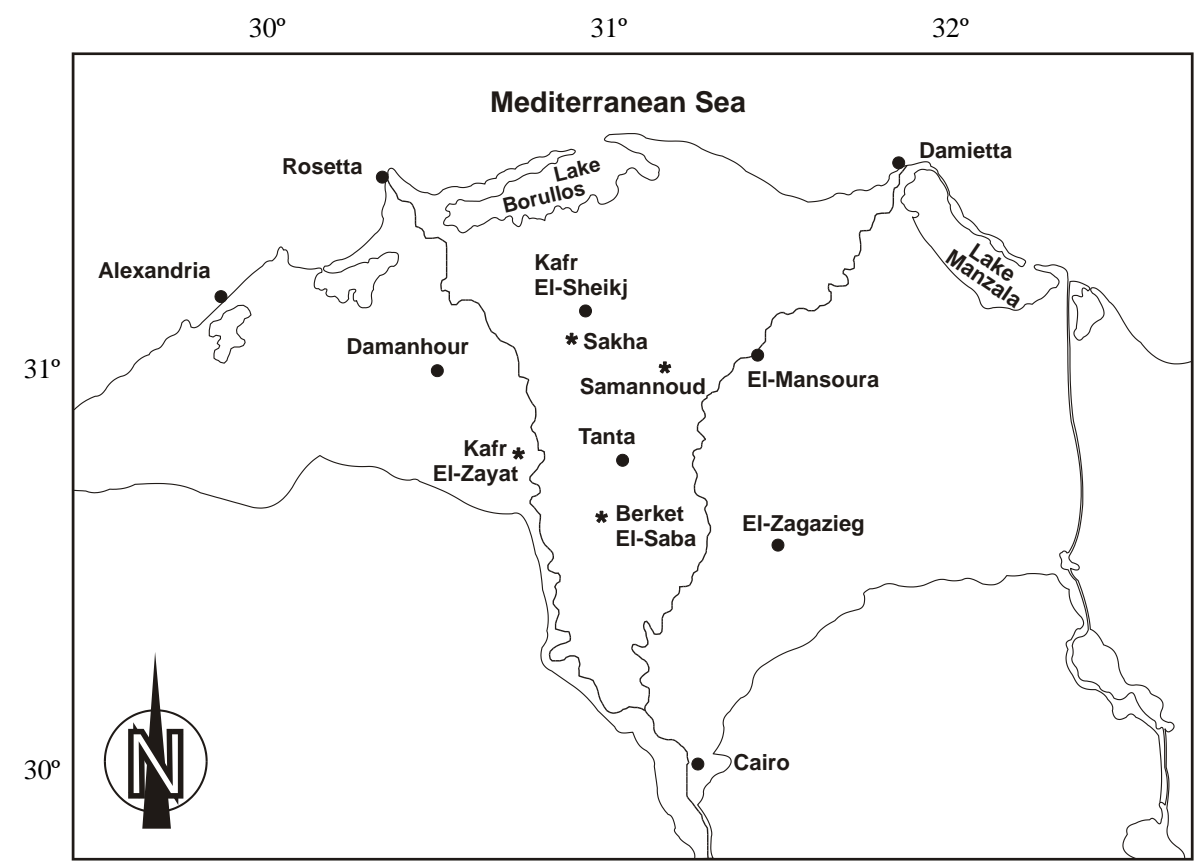

Fig. 1. Map of the Nile Delta, Egypt, *: study locality.

\section{Methods}

Twenty-five permanent sites (1 x 1m) in each season of 1998 were selected to represent Phragmites australis along 15 canals and 10 drains distributed in 5 localities within the study area, as well as three width classes of canals $(<5,5-10,>10 \mathrm{~m})$ and two classes of drains $(5-10,>10 \mathrm{~m})$. In each site the shoots of the plant were harvested, separated into living and dead parts and weighted. The oven dry weights at $105^{\circ} \mathrm{C}$ were also estimated and the weight of living parts, dead parts, total phytomass and living/dead ratio were calculated. Composite samples were collected from living and others from dead parts of the shoot of each site, cleaned, dried at $65^{\circ} \mathrm{C}$, and powdered in a metal- free plastic mill. $\mathrm{Na}, \mathrm{K}$ and $\mathrm{Ca}$ were analyzed using the flame photometer, $\mathrm{Fe}, \mathrm{Mg}, \mathrm{Cu}, \mathrm{Mn}, \mathrm{Zn}, \mathrm{Pb}$ and $\mathrm{Co}$ by atomic absorption, and $\mathrm{P}$ and $\mathrm{N}$ by spectrophotometer. Ash content was estimated by ignition at $500^{\circ} \mathrm{C}$ for about 24 hours. All these procedures are according to Allen et al. (1974). Ether extract (total lipids) was determined by extracting the plant with ether (König 1969). Crude protein (CP) was calculated by multiplying the insoluble nitrogen by the factor 6.25 (Pirie 1955; Ölberg 1965). Crude fiber (CF) was estimated according to Scharrer \& Kürschner (1967). Digestible crude protein (DCP) was calculated accordig to the equation of Demarquilly \& Weiss (1970):

$$
\mathrm{DCP}(\% \mathrm{DM})=0.929 \mathrm{CP}(\% \mathrm{DM})-3.52 \text {. }
$$


Carbohydrates (NFE) were calculated from the following equation (Le Houérou 1980):

$$
\mathrm{NFE}(\% \mathrm{DM})=100-(\mathrm{CP}+\mathrm{CF}+\mathrm{Fat}+\mathrm{Ash}) .
$$

Total digestible nutrients (TDN) were calculated according to this equation (selected from Naga \& El-Shazly's 1971 regression models according to the range of protein and fiber percentage in the plant):

$$
\mathrm{TDN}(\% \text { in } \mathrm{DM})=0.5(100+1.25 \mathrm{EE})-\mathrm{PK},
$$

Where $\mathrm{EE}$ is the percentage of ether extract fraction, $\mathrm{P}$ is the percentage of crude protein, and $\mathrm{K}$ is a coefficient, which depends on the protein and fiber contents $(=0.7)$.

Digestible energy (DE) was estimated from the following formula (NRC 1984):

$\mathrm{DE}(\mathrm{Mcal} / \mathrm{kg})=0.0504 \mathrm{CP} \%+0.077 \mathrm{EE} \%+0.02 \mathrm{CF} \%+0.000377 \mathrm{NFE} \%+0.011 \mathrm{NFE} \%$ -0.152 .

Metabolize energy $(\mathrm{ME})=0.82 \mathrm{DE}$ as mentioned by Garrett $(1980)$, net energy $(\mathrm{NE})=1 / 2$ ME and gross energy (GE) was calculated according to the relationship of (NRC 1984):

$$
\mathrm{GE}(\mathrm{Kcal} / 100 \mathrm{gm})=5.72 \mathrm{CP}+9.5 \mathrm{EE}+4.79 \mathrm{CF}+4.03 \mathrm{NFE} .
$$

Nutritional ratio (NR) was calculated according to Le Houèrou (1980):

$$
\mathrm{NR}=\mathrm{DP}(\mathrm{g} / \mathrm{kg} \mathrm{DM}) / \mathrm{NE}(\mathrm{FU} / \mathrm{kg} \mathrm{DM}) .
$$

Where one $\mathrm{FU}=6.9 \mathrm{MJ}=1650 \mathrm{kcal}$.

A three - way ANOVA was applied to assess the significance of variation in standing crop phytomass, elements, organic components and nutritive value in relation to canal width, canal type and season. T- test was applied to assess the significance of variation in the organic components of the living and dead parts. These statistical were according to SAS software (SAS 1985).

\section{Results}

The living and dead parts and the total aboveground phytomass of Phragmites australis have the highest values in autumn (1418.7, 419.8, $1838.4 \mathrm{gm} \mathrm{D} \mathrm{M} / \mathrm{m}^{2}$, respectively), and the lowest values in winter $\left(374.0,96.0,470.0 \mathrm{gm} \mathrm{DM} / \mathrm{m}^{2}\right.$, respectively). Living/dead ratio has the highest value in spring (5.19), and the lowest in summer (3.26). According to the type of water courses, it is clear that living parts from drains (1086.0) are from higher than those from canals (774.4), but the reverse is true for the dead parts (Table 1). The total phytomass and the living/dead ratio in the drains are higher than those in canals. Comparing width of water courses, it is clear that living parts and living/dead ratios in the canals increase with the increase in canal width, but the dead parts decrease with increasing the width. Living and dead parts and total phytomass in drains decrease with increasing the drain width, but reverse is true for living/dead ratios. 
Table 1. Variations in the above - ground phytomass of living and dead parts (gm dry weight / $\mathrm{m}^{2}$ ) of Phragmites australis in relaion to different seasons, canal - drain width and type of water courses. CxS: interaction between canal type and seasons and $\mathrm{WxCxS}$ : interaction between canal width, canal type and season. ***: $\mathrm{P}<0.01$, *: $\mathrm{P}<0.05$, and ns: insignificant different $(\mathrm{P}>0.05)$ according to three- way ANOVA.

\begin{tabular}{|c|c|c|c|c|}
\hline Variable & Living parts & Dead parts & Total phytomass & $\begin{array}{l}\text { Living / Dead } \\
\text { ratio }\end{array}$ \\
\hline Winter & $374.0 \pm 207.9$ & $96.1 \pm 129.6$ & $470.1 \pm 308.7$ & $3.9 \pm 3.9$ \\
\hline Spring & $788.1 \pm 352.8$ & $151.8 \pm 167.9$ & $939.9 \pm 518.8$ & $5.2 \pm 14.1$ \\
\hline Summer & $1058.7 \pm 573.8$ & $324.1 \pm 306.0$ & $1382.8 \pm 881.0$ & $3.3 \pm 5.7$ \\
\hline Autumn & $1418.7 \pm 439.3$ & $419.8 \pm 349.1$ & $1838.4 \pm 868.4$ & $3.4 \pm 7.0$ \\
\hline F-value & $24.59 * * *$ & $6.81 * * *$ & $14.82 * * *$ & Ns \\
\hline \multicolumn{5}{|c|}{ Type of water courses } \\
\hline Canal & $774.4 \pm 443.6$ & $472.4 \pm 456.7$ & $1246.8 \pm 814.4$ & $1.6 \pm 7.5$ \\
\hline Drain & $1086.0 \pm 647.6$ & $336.8 \pm 339.7$ & $1422.8 \pm 520.0$ & $3.2 \pm 3.2$ \\
\hline F-value & ns & $\mathrm{ns}$ & $\mathrm{ns}$ & $\mathrm{ns}$ \\
\hline \multicolumn{5}{|c|}{ Width of water courses } \\
\hline \multicolumn{5}{|l|}{ Canal } \\
\hline$<5 \mathrm{~m}$ & $646.14 \pm 427.0$ & $330.9 \pm 315.2$ & $977.1 \pm 528.0$ & $1.95 \pm 2.6$ \\
\hline $5-10 \mathrm{~m}$ & $717.8 \pm 339.6$ & $193.0 \pm 143.8$ & $910.8 \pm 410.0$ & $3.7 \pm 4.6$ \\
\hline$>10 \mathrm{~m}$ & $907.9 \pm 524.0$ & $75.2 \pm 113.8$ & $983.1 \pm 540.0$ & $12.1 \pm 8.3$ \\
\hline \multicolumn{5}{|c|}{ Drain } \\
\hline $5-10 \mathrm{~m}$ & $1031.2 \pm 658.0$ & $299.7 \pm 328.3$ & $1330.9 \pm 765.0$ & $3.4 \pm 4.9$ \\
\hline$>10 \mathrm{~m}$ & $1140.8 \pm 649.3$ & $373.9 \pm 355.3$ & $1514.8 \pm 850.0$ & $3.1 \pm 6.3$ \\
\hline F-value & $9.05 * * *$ & $4.71 * * *$ & $7.40 * * *$ & $\mathrm{~ns}$ \\
\hline \multicolumn{5}{|c|}{ F-interaction } \\
\hline $\mathrm{CxS}$ & $14.04 * * *$ & $4.65 * * 8$ & $9.16^{* * * *}$ & ns \\
\hline WxCxS & $\mathrm{ns}$ & $\mathrm{ns}$ & $\mathrm{ns}$ & ns \\
\hline
\end{tabular}

Living parts have the highest concentration of $\mathrm{K}(21.5 \mathrm{mg} / \mathrm{g})$ and $\mathrm{Ca}(10.5 \mathrm{mg} / \mathrm{g})$ in winter, but the lowest of $\mathrm{Na}(7.6 \mathrm{mg} / \mathrm{g})$ and $\mathrm{Mg}(4.1 \mathrm{mg} / \mathrm{g})$ in summer, $\mathrm{Fe}(0.2 \mathrm{mg} / \mathrm{g})$ in winter and $\mathrm{Cu}(10.4 \mathrm{ppm})$ in autumn (Table 2). The dead parts have the highest concentrations of $\mathrm{Na}(11.5 \mathrm{mg} / \mathrm{g})$ and $\mathrm{Mn}(112 \mathrm{ppm})$ in summer, $\mathrm{Fe}(0.9 \mathrm{mg} / \mathrm{g}), \mathrm{Cu}$ $(24.9 \mathrm{mg} / \mathrm{g})$ and $\mathrm{Zn}(296.7 \mathrm{mg} / \mathrm{g})$ in spring, and $\mathrm{Mg}(7.4 \mathrm{mg} / \mathrm{g}), \mathrm{Pb}(97.0 \mathrm{ppm})$ and $\mathrm{Co}$ (34.7ppm) in autumn. The low concentrations of $\mathrm{Pb}(44.5 \mathrm{ppm})$ are in winter, Mn (71.4ppm) in spring, Zn (11.4ppm) and Co (4.9ppm) in summer and $\mathrm{K}(9.3 \mathrm{mg} / \mathrm{g})$ and $\mathrm{Ca}$ $(5.7 \mathrm{mg} / \mathrm{g})$ in autumn. Comparing the water courses, it is clear that living parts of canals have the highest concentrations of $\mathrm{K}(20.0 \mathrm{mg} / \mathrm{g})$ and $\mathrm{P}(0.3 \mathrm{mg} / \mathrm{g})$, but the lowest of $\mathrm{Na}$, $\mathrm{Fe}, \mathrm{Cu}, \mathrm{Mn}, \mathrm{Zn}, \mathrm{Pb}$ and $\mathrm{Co}$. The living parts of drains have the highest concentration of $\mathrm{Ca}(10.1 \mathrm{ppm}), \mathrm{Mn}(105.9 \mathrm{ppm})$ and Co (17.5ppm), but the lowest of $\mathrm{Fe}$ and $\mathrm{Cu}$. Dead parts of canals have the highest concentration of $\mathrm{Cu}(19.2 \mathrm{ppm})$, but the lowest of $\mathrm{Ca}, \mathrm{Mg}$ and P. Dead parts of drains have highest concentrations of $\mathrm{Na}(12.0 \mathrm{mg} / \mathrm{g}), \mathrm{Fe}(0.7 \mathrm{mg} / \mathrm{g})$, $\mathrm{Mg}(6.4 \mathrm{mg} / \mathrm{g}), \mathrm{Zn}(121.4 \mathrm{ppm})$ and $\mathrm{Pb}(94.5 \mathrm{ppm})$, but the lowest of $\mathrm{K}$.

Comparing the nutrient contents according to the width of water courses (Table $2)$, it is clear that the living parts in narrow canals $(<5 \mathrm{~m})$ have the highest values of $\mathrm{P}(0.3$ 
$\mathrm{mg} / \mathrm{g}), \mathrm{Cu}(24.0 \mathrm{ppm})$ and $\mathrm{Mn}(158.1 \mathrm{ppm})$, but the lowest of $\mathrm{Pb}(42.9 \mathrm{ppm})$, while the dead parts have the lowest values of $\mathrm{Na}, \mathrm{K}, \mathrm{Ca}, \mathrm{Mg}$ and $\mathrm{P}$. The living parts of the medium canals $(5-10 \mathrm{~m})$ have the highest values of $\mathrm{K}$ and $\mathrm{Ca}(20.5$ and $9.6 \mathrm{mg} / \mathrm{g}$, respectively), but the lowest of $\mathrm{Cu}$ and $\mathrm{Co}$, while dead parts have the highest of $\mathrm{Fe}, \mathrm{Mg}, \mathrm{Zn}$ and $\mathrm{Pb}(0.7$ and $6.4 \mathrm{mg} / \mathrm{g}$ and 153.2 and $70.4 \mathrm{ppm}$, respectively) and the lowest of $\mathrm{P}(0.1 \mathrm{mg} / \mathrm{g})$. The living parts of wide canals $(>10 \mathrm{~m})$ have the lowest values of $\mathrm{Fe}(0.2 \mathrm{mg} / \mathrm{g}), \mathrm{Mn}(47.9 \mathrm{ppm})$ and $\mathrm{Zn}(30.0 \mathrm{ppm})$. The living parts of drains $(5-10 \mathrm{~m})$ have the highest values of $\mathrm{Ca}(10.2$ $\mathrm{mg} / \mathrm{g}$ ) and $\mathrm{Co}(27.1 \mathrm{ppm})$, but the dead parts have the highest of $\mathrm{Mg}(7.4 \mathrm{mg} / \mathrm{g})$ and $\mathrm{Pb}$ $(95.7 \mathrm{ppm})$. The highest values of $\mathrm{Na}$ and $\mathrm{Fe}$ are attained in wide drains (> 10m) (12.6 and $0.7 \mathrm{mg} / \mathrm{g}$, respectively).

The living parts have the highest total nitrogen (TN), total protein (TP) and ether extract (EE) in spring $(1.29,8.13$ and $2.46 \%$, respectively), but the lowest concentrations of EE (1.18\%) in autumn and crude fiber; CF (27.84\%) in spring (Table 3). On the other hand, dead parts have the highest total carbohydrates; NFE (50.97\%) and ash (12.81\%) in summer and CF (44.48\%) in spring, but the lowest TN, TP and ash in autumn $(0.30,1.91$ and $9.35 \%$, respectively). Comparing the organic components according to the type of watercourses, it is clear that living parts from canals have the highest percentages of EE and ash (1.95 and $11.17 \%$, respectively), but has the lowest value of CF (29.6\%). The dead parts from canals have the lowest percentages of NFE, TN, TP and EE (47.04, 0.34, 2.35 and $1.57 \%$, respectively), but the highest of CF (38.47\%). The living parts from drains have the highest values of NFE, TN and TP (50.68, 1.06 and 6.69\%, respectively), while the dead parts have the lowest of ash (10.1\%).

According to the width of water courses (Table 3), living parts of narrow canals $(<5 \mathrm{~m})$ have the highest values of EE and ash $(2.3$ and $11.73 \%$, respectively), but the dead parts have the highest of TP $(2.28 \%)$. The living parts of medium canals $(5-10 \mathrm{~m})$ have the highest values of NFE and TN (52.09 and 1.15\%, respectively), while dead parts have the highest value of CF (43.73\%), and the lowest of NFE, EE and ash (43.36, 1.53 and 9.09\%, respectively). The dead parts of wide canals $(>10 \mathrm{~m})$ have the lowest values of TN and TP ( 0.3 and $1.89 \%$, respectively). The living parts of wide drains $(>10 \mathrm{~m})$ have the lowest value of $\mathrm{CF}(29.1 \%)$.

In spring, the living parts have the highest values of digestible crude protein (DCP), Total digestible nutrients (TDN), digestible energy (DE) metabolize energy (ME) and net energy (NE) (4.0 and $63.1 \%$ and $2.54,2.08$ and $1.04 \mathrm{Mcal} / \mathrm{kg}$, respectively), while the dead parts have the lowest values of TDN, DE, ME and NE $(52.5 \%$ and 2.1, 1.73 and $0.86 \mathrm{Mcal} / \mathrm{kg}$, respectively) (Table 4). Comparing the type of water courses, the living parts from drains have the highest values of TDN, DE, ME and NE (61.6\% and 2.46, 2.02 and $1.0 \mathrm{Mcal} / / \mathrm{kg}$, respectively), while the dead parts have the highest of GE $(403.96 \mathrm{Kcal} / 100 \mathrm{mg})$, and the lowest of NE $(0.95 \mathrm{Mcal} / \mathrm{kg})$. The living parts from canals have the highest of DCP $(2.66 \%)$ and NE $(1.0 \mathrm{Mcal} / \mathrm{kg})$, while the dead parts have the lowest of DCP, TDN, DE, ME and GE (0.1 and 56.87\%, 2.18 and $1.79 \mathrm{Mcal} / \mathrm{kg}$ and 399.8 $\mathrm{Kcal} / 100 \mathrm{mg}$, respectively). The living parts of wide drains $(>10 \mathrm{~m})$ have the highest of $\mathrm{DE}, \mathrm{ME}$ and $\mathrm{NE}(2.53,2.08$ and $1.03 \mathrm{Mcal} / \mathrm{Kgm}$, respectively). On the other hand, the dead parts of medium drains $(5-10 \mathrm{~m})$ have the lowest of DCP $(0.1 \%)$. The dead parts of narrow canals $(<5 \mathrm{~m})$ have the lowest of TDN $(52.52 \%)$. On the other hand, the dead parts of canals $(5-10 \mathrm{~m})$ have the highest of GE $(411.72 \mathrm{Kcal} / 100 \mathrm{mg})$ and the lowest of DE, $\mathrm{ME}$, and $\mathrm{NE}(2.14,1.76$ and $0.88 \mathrm{Mcal} / \mathrm{kg}$, respectively), and the living parts have the highest of DCP $(3.22 \%)$. The dead parts of wide drains $(>10 \mathrm{~m})$ have the highest TDN $(62.5 \%)$ and the lowest GE $(385.3 \mathrm{Kcal} / 100 \mathrm{mg})$. 
Table 2. Variation in the mean concentration \pm standard deviation of eleven nutrients in the above - ground living and dead parts of Phragmites australis in relation to different seasons, canal - drain width and type of water courses. CxS: interaction between canal type and season and WxCxS: interaction between canal width, canal types and season. ***: $P<0.1$, *: $P<.05$ and ns: insignificant different $(P>0.05)$ according to three-way ANOVA.

\begin{tabular}{|c|c|c|c|c|c|c|c|c|c|c|c|c|}
\hline \multirow{4}{*}{ Variable } & & \multicolumn{11}{|c|}{ Elements } \\
\hline & & \multicolumn{6}{|c|}{ Mg/g } & \multicolumn{5}{|c|}{ ppm } \\
\hline & & $\mathbf{N a}$ & $\mathbf{K}$ & $\mathrm{Ca}$ & $\mathbf{F e}$ & Mg & $\mathbf{P}$ & $\mathrm{Cu}$ & Mn & $\mathbf{Z n}$ & $\mathbf{P b}$ & Co \\
\hline & & \multicolumn{11}{|c|}{ Seasons } \\
\hline \multirow{2}{*}{ Winter } & & $8.5 \pm 0.4$ & $21.5 \pm 0.3$ & $10.5 \pm 0.1$ & $0.2 \pm 0.0$ & $6.3 \pm 0.4$ & $0.2 \pm 0.1$ & $15.5 \pm 8.4$ & $110.9 \pm 100$ & $26.7 \pm 13.7$ & $64.1 \pm 42.9$ & $14.4 \pm 10.3$ \\
\hline & D & $9.3 \pm 0.3$ & $18.3 \pm 0.1$ & $6.7 \pm 0.1$ & $0.3 \pm 0.0$ & $6.2 \pm 0.3$ & $0.1 \pm 0.0$ & $18.3 \pm 9.7$ & $101.6 \pm 49.8$ & $73.8 \pm 123.7$ & $44.5 \pm 17.6$ & $9.7 \pm 5.8$ \\
\hline \multirow{2}{*}{ Spring } & $\mathbf{L}$ & $7.7 \pm 0.4$ & $20.5 \pm 0.3$ & $9.8 \pm 0.1$ & $0.3 \pm 0.0$ & $6.1 \pm 0.3$ & $0.2 \pm 0.0$ & $23.3 \pm 7.7$ & $97.7 \pm 55.1$ & $38.9 \pm 15.3$ & $75.9 \pm 63.6$ & $9.1 \pm 5.7$ \\
\hline & D & $9.0 \pm 0.4$ & $11.6 \pm 0.3$ & $7.3 \pm 0.2$ & $0.9 \pm 0.0$ & $4.7 \pm 0.1$ & $0.1 \pm 0.0$ & $24.9 \pm 7.6$ & $71.3 \pm 11.0$ & $296.7 \pm 8.6$ & $58.6 \pm 19.7$ & $5.8 \pm 6.1$ \\
\hline \multirow{2}{*}{ Summer } & $\mathbf{L}$ & $7.6 \pm 0.1$ & $20.2 \pm 0.4$ & $10.0 \pm 0.2$ & $0.3 \pm 0.0$ & $4.1 \pm 0.4$ & $0.2 \pm 0.0$ & $11.9 \pm 13.0$ & $83.2 \pm 54.9$ & $44.0 \pm 23.4$ & $57.1 \pm 88.3$ & $8.8 \pm 3.9$ \\
\hline & D & $11.5 \pm 0.4$ & $9.6 \pm 0.4$ & $7.6 \pm 0.2$ & $0.4 \pm 0.0$ & $4.7 \pm 0.3$ & $0.1 \pm 0.0$ & $11.6 \pm 7.9$ & $112.2 \pm 64.0$ & $11.4 \pm 4.1$ & $91.6 \pm 44.5$ & $4.9 \pm 3.3$ \\
\hline \multirow{2}{*}{ Autumn } & $\mathbf{L}$ & $8.9 \pm 0.4$ & $15.5 \pm 0.5$ & $8.2 \pm 0.2$ & $0.3 \pm 0.0$ & $6.7 \pm 0.5$ & $0.3 \pm 0.0$ & $10.4 \pm 12.7$ & $88.5 \pm 61.3$ & $21.0 \pm 9.5$ & $75.9 \pm 83.3$ & $18.7 \pm 16.1$ \\
\hline & D & $7.8 \pm 0.4$ & $9.1 \pm 0.3$ & $5.7 \pm 0.2$ & $0.7 \pm 0.0$ & $7.4 \pm 0.1$ & $0.1 \pm 0.0$ & $17.9 \pm 16.1$ & $111.3 \pm 19.2$ & $73.4 \pm 123.3$ & $97.0 \pm 13.5$ & $34.7 \pm 6.8$ \\
\hline \multirow{3}{*}{ F-value } & $\mathbf{L}$ & Ns & ns & $5.57 * * *$ & ns & ns & ns & Ns & ns & ns & ns & Ns \\
\hline & D & 3.63* & $15.63 * * *$ & Ns & $12.2 * * *$ & ns & ns & ns & ns & 7.74*** & $15.63 * * *$ & $51.86 * * *$ \\
\hline & & \multicolumn{11}{|c|}{ Type of water courses } \\
\hline \multirow{2}{*}{ Canal } & $\mathbf{L}$ & $6.4 \pm 0.2$ & $20.0 \pm 0.4$ & $9.2 \pm 0.2$ & $0.3 \pm 0.0$ & $6.0 \pm 0.4$ & $0.3 \pm 0.0$ & $15.4 \pm 11.6$ & $86.9 \pm 81.4$ & $32.0 \pm 16.6$ & $\mathbf{5 3 . 7} \pm \mathbf{5 3 . 5}$ & $9.6 \pm 4.4$ \\
\hline & D & $7.6 \pm 0.3$ & $12.4 \pm 0.4$ & $6.2 \pm 0.1$ & $0.6 \pm 0.0$ & $5.3 \pm 0.2$ & $0.1 \pm 0.0$ & $19.2 \pm 11.0$ & $101.3 \pm 50.6$ & $108.6 \pm 138.4$ & $58.5 \pm 23.8$ & $13.1 \pm 13.2$ \\
\hline \multirow{2}{*}{ Drain } & $\mathbf{L}$ & $11.5 \pm 0.4$ & $18.7 \pm 0.5$ & $10.1 \pm 0.2$ & $0.3 \pm 0.0$ & $5.6 \pm 0.3$ & $0.2 \pm 0.0$ & $15.4 \pm 11.8$ & $105.9 \pm 49.6$ & $33.5 \pm 20.8$ & $87.2 \pm 86.0$ & $17.5 \pm 14.5$ \\
\hline & D & $12.0 \pm 0.3$ & $11.8 \pm 0.5$ & $7.8 \pm 0.2$ & $0.7 \pm 0.0$ & $6.4 \pm 0.2$ & $0.1 \pm 0.0$ & $15.7 \pm 10.2$ & $95.8 \pm 28.0$ & $121.4 \pm 144.9$ & $94.5 \pm 35.2$ & $14.8 \pm 14.9$ \\
\hline
\end{tabular}


Table 2. continued.

\begin{tabular}{|c|c|c|c|c|c|c|c|c|c|c|c|c|}
\hline \multirow{4}{*}{$\begin{array}{c}\text { Variabl } \\
\mathbf{e}\end{array}$} & & \multicolumn{11}{|c|}{ Elements } \\
\hline & & \multicolumn{6}{|c|}{ Mg/g } & \multicolumn{5}{|c|}{ ppm } \\
\hline & & $\mathbf{N a}$ & $\mathbf{K}$ & $\mathbf{C a}$ & $\mathbf{F e}$ & Mg & $\mathbf{P}$ & $\mathbf{C u}$ & Mn & $\mathbf{Z n}$ & $\mathbf{P b}$ & Co \\
\hline & & \multicolumn{11}{|c|}{ Seasons } \\
\hline \multirow{2}{*}{ F-value } & $\mathbf{L}$ & Ns & ns & ns & ns & ns & ns & ns & ns & ns & ns & ns \\
\hline & D & $27.56 * * *$ & ns & ns & ns & ns & ns & ns & ns & ns & $30.09 * * *$ & ns \\
\hline Canal & & \multicolumn{11}{|c|}{ Width of water courses } \\
\hline \multirow{2}{*}{$<5 \mathrm{~m}$} & $\mathbf{L}$ & $5.8 \pm 0.1$ & $18.5 \pm 0.5$ & $8.8 \pm 0.2$ & $0.3 \pm 0.0$ & $5.5 \pm 0.4$ & $0.3 \pm 0.0$ & $24.0 \pm 13.0$ & $16.1 \pm 96.0$ & $32.2 \pm 18.3$ & $42.9 \pm 17.5$ & $8.7 \pm 1.4$ \\
\hline & D & $5.7 \pm 0.1$ & $11.1 \pm 0.5$ & $5.0 \pm 0.1$ & $0.4 \pm 0.0$ & $4.4 \pm 0.3$ & $0.1 \pm 0.0$ & $20.1 \pm 14.0$ & $108.3 \pm 59.2$ & $82.9 \pm 135.0$ & $54.3 \pm 17.9$ & $11.7 \pm 12.4$ \\
\hline \multirow{2}{*}{$5-10 \mathrm{~m}$} & $\mathbf{L}$ & $6.6 \pm 0.2$ & $20.5 \pm 0.3$ & $9.6 \pm 0.1$ & $0.3 \pm 0.0$ & $5.9 \pm 0.5$ & $0.3 \pm 0.0$ & $11.7 \pm 10.1$ & $83.0 \pm 80.0$ & $33.9 \pm 17.2$ & $65.4 \pm 61.8$ & $7.1 \pm 2.6$ \\
\hline & D & $7.3 \pm 0.2$ & $13.1 \pm 0.4$ & $6.7 \pm 0.1$ & $0.7 \pm 0.0$ & $6.5 \pm 0.2$ & $0.1 \pm 0.0$ & $16.5 \pm 8.5$ & $76.4 \pm 10.0$ & $153.2 \pm 165.2$ & $70.4 \pm 27.9$ & $12.5 \pm 15.6$ \\
\hline \multirow{2}{*}{$>10 \mathrm{~m}$} & $\mathbf{L}$ & $6.1 \pm 0.2$ & $20.4 \pm 0.5$ & $9.0 \pm 0.2$ & $0.2 \pm 0.0$ & $6.3 \pm 0.4$ & $0.2 \pm 0.0$ & $13.8 \pm 10.1$ & $47.9 \pm 38.0$ & $30.0 \pm 15.7$ & $48.5 \pm 58.8$ & $13.2 \pm 5.8$ \\
\hline & D & $9.9 \pm 0.3$ & $12.9 \pm 0.4$ & $6.7 \pm 0.1$ & $0.6 \pm 0.0$ & $4.9 \pm 0.1$ & $0.2 \pm 0.0$ & $21.2 \pm 12.0$ & $119.2 \pm 66.0$ & $89.8 \pm 143.6$ & $50.9 \pm 26.3$ & $15.1 \pm 15.3$ \\
\hline \multicolumn{13}{|l|}{ Drain } \\
\hline \multirow{2}{*}{$5-10 \mathrm{~m}$} & $\mathbf{L}$ & $11.1 \pm 0.4$ & $19.6 \pm 0.6$ & $10.2 \pm 0.2$ & $0.3 \pm 0.0$ & $5.2 \pm 0.3$ & $0.2 \pm 0.0$ & $13.8 \pm 11.3$ & $118.5 \pm 49.0$ & $30.9 \pm 21.9$ & $87.5 \pm 71.9$ & $27.1 \pm 15.3$ \\
\hline & $\mathbf{D}$ & $11.4 \pm 0.4$ & $12.7 \pm 0.5$ & $7.6 \pm 0.2$ & $0.6 \pm 0.0$ & $7.4 \pm 0.6$ & $0.1 \pm 0.0$ & $13.6 \pm 10.7$ & $97.1 \pm 36.4$ & $89.9 \pm 143.5$ & $95.7 \pm 32.4$ & $16.5 \pm 14.7$ \\
\hline \multirow{2}{*}{$>10 \mathrm{~m}$} & $\mathbf{L}$ & $11.8 \pm 0.4$ & $17.9 \pm 0.5$ & $10.1 \pm 0.14$ & $0.3 \pm 0.0$ & $6.0 \pm 0.4$ & $0.2 \pm 0.0$ & $16.9 \pm 12.4$ & $93.0 \pm 47.4$ & $36.0 \pm 19.8$ & $86.9 \pm 100.0$ & $7.8 \pm 3.3$ \\
\hline & D & $12.6 \pm 0.29$ & $11.0 \pm 0.65$ & $7.9 \pm 0.2$ & $0.7 \pm 0.0$ & $5.5 \pm 0.2$ & $0.1 \pm 0.0$ & $17.8 \pm 10.9$ & $94.5 \pm 24.0$ & $152.9 \pm 160.4$ & $93.4 \pm 42.9$ & $9.7 \pm 11.4$ \\
\hline \multirow{2}{*}{ F-value } & $\mathbf{L}$ & $13.81 * * *$ & $2.44 *$ & 4.32* & ns & ns & ns & ns & ns & ns & ns & Ns \\
\hline & $\mathbf{D}$ & $3.75 *$ & ns & ns & ns & ns & ns & ns & ns & ns & ns & 4.00* \\
\hline \multicolumn{13}{|c|}{ F-interaction } \\
\hline $\mathrm{CxS}$ & $\mathbf{L}$ & $2.39 *$ & ns & $6.02 * *$ & ns & ns & ns & ns & ns & ns & ns & ns \\
\hline WxCxS & $\mathbf{L}$ & ns & ns & ns & ns & ns & ns & ns & ns & ns & ns & ns \\
\hline
\end{tabular}


Table 3. Variation in the mean organic contents in the above - ground living (L) and dead parts (D) of Phragmites australis in relation to different seasons, canal - drain width and type of water courses. NFE: total carbohydrate, TN: total nitrogen, TP: total protein, EE: ether extract, CF: crude fiber. CxS: interaction between canal type and season and $\mathrm{WxCxS}$ : interaction between canal width, canal type and season. $* * *: \mathrm{P} \leq 0.01,: \mathrm{P} \leq 0.05$, and ns: insignificant different ( $\mathrm{P} \geq 0.05$ ) according to three- way ANOVA.

\begin{tabular}{|c|c|c|c|c|c|c|c|}
\hline \multirow{2}{*}{ Variable } & & \multicolumn{6}{|c|}{ Organic component (\%) } \\
\hline & & NFE & $\mathrm{TN}$ & $\mathrm{TP}$ & $\mathrm{EE}$ & $\mathrm{CF}$ & Ash \\
\hline \multicolumn{8}{|c|}{ Season } \\
\hline \multirow{2}{*}{ Winter } & $\mathrm{L}$ & $51.04 \pm 4.34$ & $0.99 \pm 0.58$ & $6.24 \pm 3.66$ & $1.78 \pm 0.52$ & $30.20 \pm 3.53$ & $10.62 \pm 1.00$ \\
\hline & $\mathrm{D}$ & $47.94 \pm 6.17$ & $0.50 \pm 0.30$ & $3.12 \pm 1.90$ & $1.63 \pm 0.54$ & $35.78 \pm 7.57$ & $10.57 \pm 2.48$ \\
\hline \multirow{2}{*}{ Spring } & $\mathrm{L}$ & $49.00 \pm 2.74$ & $1.29 \pm 0.43$ & $8.13 \pm 2.75$ & $2.46 \pm 0.15$ & $27.84 \pm 1.30$ & $12.56 \pm 2.55$ \\
\hline & $\mathrm{D}$ & $43.38 \pm 4.07$ & $0.33 \pm 0.26$ & $2.07 \pm 1.68$ & $1.50 \pm 0.58$ & $44.48 \pm 7.53$ & $9.56 \pm 3.54$ \\
\hline \multirow{2}{*}{ Summer } & $\mathrm{L}$ & $52.32 \pm 2.62$ & $0.70 \pm 0.18$ & $4.45 \pm 1.13$ & $2.10 \pm 0.40$ & $30.72 \pm 2.54$ & $10.39 \pm 0.89$ \\
\hline & $\mathrm{D}$ & $50.97 \pm 2.09$ & $0.47 \pm 0.19$ & $2.95 \pm 1.18$ & $1.82 \pm 0.76$ & $31.69 \pm 3.67$ & $12.81 \pm 3.49$ \\
\hline \multirow{2}{*}{ Autumn } & $\mathrm{L}$ & $50.05 \pm 4.43$ & $1.24 \pm 0.33$ & $7.78 \pm 2.07$ & $1.18 \pm 0.47$ & $30.59 \pm 1.56$ & $10.39 \pm 1.31$ \\
\hline & $\mathrm{D}$ & $49.39 \pm 4.59$ & $0.30 \pm 0.14$ & $1.91 \pm 0.91$ & $1.54 \pm 0.95$ & $37.80 \pm 3.67$ & $9.35 \pm 2.17$ \\
\hline \multirow{3}{*}{ F-value } & $\mathrm{L}$ & ns & ns & ns & Ns & ns & ns \\
\hline & $\mathrm{D}$ & $3.90 *$ & ns & ns & Ns & $9.36 * * *$ & ns \\
\hline & & \multicolumn{6}{|c|}{ Type of water course } \\
\hline \multirow{2}{*}{ Canal } & $\mathrm{L}$ & $50.57 \pm 3.80$ & $1.05 \pm 0.42$ & $6.63 \pm 2.67$ & $1.95 \pm 0.61$ & $29.62 \pm 2.83$ & $11.17 \pm 2.14$ \\
\hline & $\mathrm{D}$ & $47.04 \pm 5.25$ & $0.34 \pm 0.19$ & $2.35 \pm 1.26$ & $1.57 \pm 0.71$ & $38.47 \pm 7.46$ & $10.88 \pm 3.38$ \\
\hline \multirow{2}{*}{ Drain } & $\mathrm{L}$ & $50.68 \pm 3.44$ & $1.06 \pm 0.50$ & $6.69 \pm 3.17$ & $1.73 \pm 0.67$ & $30.15 \pm 2.08$ & $10.73 \pm 0.85$ \\
\hline & $\mathrm{D}$ & $49.25 \pm 4.68$ & $0.48 \pm 0.27$ & $3.04 \pm 1.72$ & $1.70 \pm 0.67$ & $35.87 \pm 7.04$ & $10.10 \pm 2.71$ \\
\hline \multirow{2}{*}{ Average } & $\mathrm{L}$ & $50.62 \pm 3.57$ & $1.06 \pm 0.44$ & $6.71 \pm 1.40$ & $1.88 \pm 0.61$ & $29.86 \pm 2.47$ & $10.99 \pm 1.73$ \\
\hline & $\mathrm{D}$ & $47.92 \pm 5.03$ & $0.41 \pm 0.18$ & $2.56 \pm 1.45$ & $1.62 \pm 0.68$ & $37.43 \pm 7.22$ & $10.57 \pm 3.08$ \\
\hline \multirow{2}{*}{ F-value } & $\mathrm{L}$ & ns & ns & ns & Ns & Ns & ns \\
\hline & $\mathrm{D}$ & $\mathrm{ns}$ & ns & ns & Ns & ns & ns \\
\hline Canal & & \multicolumn{6}{|c|}{ Width of water course } \\
\hline \multirow{2}{*}{$<5 \mathrm{~m}$} & $\mathrm{~L}$ & $48.88 \pm 2.54$ & $1.13 \pm 0.51$ & $7.47 \pm 2.50$ & $2.30 \pm 0.43$ & $29.95 \pm 3.76$ & $11.73 \pm 1.36$ \\
\hline & $\mathrm{D}$ & $46.08 \pm 5.09$ & $0.36 \pm 0.16$ & $2.28 \pm 1.03$ & $1.61 \pm 0.74$ & $40.10 \pm 3.68$ & $10.32 \pm 2.13$ \\
\hline \multirow{2}{*}{$5-10 m$} & $\mathrm{~L}$ & $52.09 \pm 5.91$ & $1.15 \pm 0.50$ & $7.75 \pm 2.51$ & $1.65 \pm 0.49$ & $28.53 \pm 2.75$ & $10.46 \pm 0.51$ \\
\hline & $\mathrm{D}$ & $43.36 \pm 4.98$ & $0.37 \pm 0.29$ & $2.33 \pm 1.81$ & $1.53 \pm 1.11$ & $43.73 \pm 8.83$ & $9.09 \pm 2.87$ \\
\hline \multirow{2}{*}{$>10 \mathrm{~m}$} & $\mathrm{~L}$ & $50.75 \pm 2.16$ & $0.88 \pm 0.29$ & $5.56 \pm 1.82$ & $1.97 \pm 0.72$ & $30.38 \pm 2.25$ & $11.32 \pm 3.69$ \\
\hline & $\mathrm{D}$ & $51.68 \pm 1.63$ & $0.30 \pm 0.14$ & $1.89 \pm 0.87$ & $1.56 \pm 0.24$ & $34.81 \pm 5.56$ & $13.26 \pm 4.11$ \\
\hline \multicolumn{8}{|l|}{ Drain } \\
\hline \multirow{2}{*}{$5-10 m$} & $\mathrm{~L}$ & $49.33 \pm 3.05$ & $1.10 \pm 0.37$ & $6.92 \pm 2.34$ & $1.72 \pm 0.74$ & $31.13 \pm 1.31$ & $10.87 \pm 0.87$ \\
\hline & $\mathrm{D}$ & $49.18 \pm 5.75$ & $0.47 \pm 0.16$ & $2.96 \pm 1.04$ & $2.08 \pm 0.70$ & $35.63 \pm 8.51$ & $10.21 \pm 3.46$ \\
\hline \multirow{2}{*}{$>10 \mathrm{~m}$} & $\mathrm{~L}$ & $52.03 \pm 3.67$ & $1.03 \pm 0.67$ & $6.45 \pm 4.22$ & $1.75 \pm 0.70$ & $29.17 \pm 2.41$ & $10.58 \pm 0.95$ \\
\hline & $\mathrm{D}$ & $49.31 \pm 4.24$ & $0.49 \pm 0.38$ & $3.11 \pm 2.41$ & $1.31 \pm 0.40$ & $36.11 \pm 6.55$ & $10.08 \pm 2.29$ \\
\hline \multirow{2}{*}{ F-value } & $\mathrm{L}$ & ns & ns & ns & ns & ns & ns \\
\hline & $\mathrm{D}$ & ns & ns & ns & ns & $6.80 * * *$ & ns \\
\hline \multicolumn{8}{|c|}{ F-interaction } \\
\hline \multirow{2}{*}{$\mathrm{CxS}$} & $\mathrm{L}$ & $\mathrm{ns}$ & ns & ns & $\mathrm{ns}$ & Ns & ns \\
\hline & $\mathrm{D}$ & ns & ns & ns & ns & Ns & ns \\
\hline \multirow{2}{*}{ WxCxS } & $\mathrm{L}$ & $\mathrm{ns}$ & ns & ns & $\mathrm{ns}$ & $\mathrm{Ns}$ & ns \\
\hline & $\mathrm{D}$ & ns & ns & ns & $\mathrm{ns}$ & $\mathrm{Ns}$ & ns \\
\hline T-value & & $1.95 *$ & - & ns & ns & $4.43 * * *$ & ns \\
\hline
\end{tabular}


Table 4. Nutritive value of the above - ground living (L) and dead parts (D) of Phragmites australis in relation to different seasons, canal - drain width and type of water courses. DCP: digestible crude protein, TDN: total digestible nutrients, DE: digestible energy, ME: metabolise energy, NE: net energy and GE: gross energ. Mcal / kgm: Mega calorie per kilogram and kcal/100 mg: kilocalorie per $100 \mathrm{mg}$. CxS: interaction between canal type and season and $\mathrm{WxCxS}$ : interaction between canal width, canal type and season. All the variations here are insignificant different $(\mathrm{P} \geq 0.05)$ according to three- way ANOVA.

\begin{tabular}{|c|c|c|c|c|c|c|c|}
\hline Variable & & $\begin{array}{c}\text { DCP } \\
\%\end{array}$ & $\begin{array}{c}\text { TDN } \\
\%\end{array}$ & $\begin{array}{c}\mathrm{DE} \\
\mathrm{Mcal} / \mathrm{kg}\end{array}$ & $\begin{array}{c}\mathrm{ME} \\
\mathrm{Mcal} / \mathrm{kg}\end{array}$ & $\begin{array}{l}\mathrm{NE} \\
\mathrm{Mcal} / \mathrm{kg}\end{array}$ & $\begin{array}{c}\text { GE } \\
\text { Kcal/100mg }\end{array}$ \\
\hline \multicolumn{8}{|c|}{ Season } \\
\hline \multirow{2}{*}{ Winter } & $\mathrm{L}$ & $2.32 \pm 3.36$ & $60.52 \pm 4.06$ & $2.43 \pm 0.14$ & $1.99 \pm 0.11$ & $0.99 \pm 0.06$ & $403.0 \pm 6.17$ \\
\hline & $\mathrm{D}$ & $0.47 \pm 1.06$ & $59.40 \pm 6.07$ & $2.06 \pm 0.34$ & $1.85 \pm 0.12$ & $0.92 \pm 0.06$ & $399.7 \pm 8.36$ \\
\hline \multirow{2}{*}{ Spring } & $\mathrm{L}$ & $4.03 \pm 2.56$ & $63.13 \pm 7.33$ & $2.54 \pm 0.14$ & $2.08 \pm 0.12$ & $1.04 \pm 0.06$ & $400.0 \pm 11.99$ \\
\hline & $\mathrm{D}$ & $0.08 \pm 0.17$ & $52.50 \pm 5.62$ & $2.10 \pm 0.10$ & $1.73 \pm 0.08$ & $0.86 \pm 0.04$ & $411.9 \pm 23.04$ \\
\hline \multirow{2}{*}{ Summer } & $\mathrm{L}$ & $0.70 \pm 0.96$ & $61.19 \pm 2.80$ & $2.42 \pm 0.08$ & $1.99 \pm 0.07$ & $0.99 \pm 0.03$ & $403.4 \pm 6.67$ \\
\hline & $\mathrm{D}$ & $0.23 \pm 0.51$ & $59.99 \pm 6.60$ & $2.28 \pm 0.07$ & $1.87 \pm 0.06$ & $0.93 \pm 0.03$ & $388.52 \pm 15.27$ \\
\hline \multirow{2}{*}{ Autumn } & $\mathrm{L}$ & $3.70 \pm 1.93$ & $60.41 \pm 6.47$ & $2.42 \pm 0.09$ & $1.99 \pm 0.07$ & $0.99 \pm 0.04$ & $403.9 \pm 4.25$ \\
\hline & $\mathrm{D}$ & - & $57.03 \pm 6.59$ & $2.29 \pm 0.19$ & $1.88 \pm 0.16$ & $0.94 \pm 0.08$ & $405.7 \pm 11.5$ \\
\hline \multicolumn{8}{|c|}{ Types of water courses } \\
\hline \multirow{2}{*}{ Canal } & $\mathrm{L}$ & $2.66 \pm 2.4$ & $61.12 \pm 5.11$ & $2.45 \pm 0.10$ & $2.01 \pm 0.08$ & $1.00 \pm 0.03$ & $402.21 \pm 8.70$ \\
\hline & $\mathrm{D}$ & $0.10 \pm 0.3$ & $56.87 \pm 6.56$ & $2.18 \pm 0.16$ & $1.79 \pm 0.13$ & $0.89 \pm 0.06$ & $399.81 \pm 17.9$ \\
\hline \multirow{2}{*}{ Drain } & $\mathrm{L}$ & $2.73 \pm 2.8$ & $61.60 \pm 5.55$ & $2.46 \pm 0.15$ & $2.02 \pm 0.13$ & $1.00 \pm 0.06$ & $403.27 \pm 5.12$ \\
\hline & $\mathrm{D}$ & $0.19 \pm 0.5$ & $57.78 \pm 6.74$ & $2.31 \pm 0.09$ & $1.89 \pm 0.07$ & $0.95 \pm 0.04$ & $403.96 \pm 15.7$ \\
\hline Canal & & \multicolumn{6}{|c|}{ Width of water courses } \\
\hline \multirow{2}{*}{$<5 \mathrm{~m}$} & $\mathrm{~L}$ & $3.11 \pm 2.9$ & $60.95 \pm 6.07$ & $2.40 \pm 0.12$ & $1.97 \pm 0.10$ & $0.98 \pm 0.05$ & $403.01 \pm 4.05$ \\
\hline & $\mathrm{D}$ & - & $52.52 \pm 6.11$ & $2.17 \pm 0.17$ & $1.78 \pm 0.14$ & $0.89 \pm 0.06$ & $402.39 \pm 8.91$ \\
\hline \multirow{2}{*}{$5-10 m$} & $\mathrm{~L}$ & $3.22 \pm 2.9$ & $61.27 \pm 5.92$ & $2.49 \pm 0.09$ & $2.04 \pm 0.07$ & $1.01 \pm 0.04$ & $402.9 \pm 7.1$ \\
\hline & $\mathrm{D}$ & $0.29 \pm 0.6$ & $55.58 \pm 6.95$ & $2.14 \pm 0.16$ & $1.76 \pm 0.13$ & $0.88 \pm 0.06$ & $411.7 \pm 15.5$ \\
\hline \multirow{2}{*}{$>10 \mathrm{~m}$} & $\mathrm{~L}$ & $1.64 \pm 1.6$ & $61.13 \pm 4.87$ & $2.46 \pm 0.06$ & $2.02 \pm 0.04$ & $1.00 \pm 0.03$ & $400.6 \pm 14.30$ \\
\hline & $\mathrm{D}$ & - & $62.50 \pm 1.60$ & $2.24 \pm 0.19$ & $1.83 \pm 0.15$ & $0.92 \pm 0.07$ & $385.3 \pm 19.49$ \\
\hline \multicolumn{8}{|l|}{ Drain } \\
\hline \multirow{2}{*}{$5-10 m$} & $\mathrm{~L}$ & $2.91 \pm 2.1$ & $60.75 \pm 6.28$ & $2.39 \pm 0.07$ & $1.96 \pm 0.05$ & $0.97 \pm 0.03$ & $403.53 \pm 2.94$ \\
\hline & $\mathrm{D}$ & $0.10 \pm 0.2$ & $58.18 \pm 9.08$ & $2.33 \pm 0.09$ & $1.91 \pm 0.07$ & $0.95 \pm 0.04$ & $405.78 \pm 20.27$ \\
\hline \multirow{2}{*}{$>10 \mathrm{~m}$} & $\mathrm{~L}$ & $2.56 \pm 3.8$ & $62.45 \pm 5.52$ & $2.53 \pm 0.19$ & $2.08 \pm 0.16$ & $1.03 \pm 0.08$ & $403.01 \pm 7.24$ \\
\hline & $\mathrm{D}$ & $0.59 \pm 1.1$ & $57.49 \pm 4.60$ & $2.29 \pm 0.10$ & $1.88 \pm 0.08$ & $0.94 \pm 0.04$ & $402.14 \pm 12.6$ \\
\hline
\end{tabular}




\section{Discussion}

The present study indicates that the average of annual above ground total phytomass of Phragmites australis (common reed) attained 3252.3 gdry $\mathrm{wt} / \mathrm{m}^{2}$. It has the high aboveground phytomass in autumn along the wide canals and drains $(>10 \mathrm{~m})$. This finding is supported by Abo Ziada (1987), Mason \& Bryant (1974), Edany \& Rezk (1981) and Boar (1996). Phytomass of Phragmites australis has been extensively studied in different parts of the world. Björk (1967) reported that eutrophication increased the shoot standing crop. Haslam (1965) found that Phragmites was a dominant species near rivers and ditches subject to silting and high available phosphates and other minerals. Under Egyptian conditions, the comparison between the production of Phragmites australis in the present study and other related studies is indicated below:

$\begin{array}{lc}\text { Reference } & \text { Standing crop (g/d } \\ \text { Present study } & 3252.3 \\ \text { Abo Ziada (1987) (Dakahlia District) } & 1159.0 \\ \text { Khedr (1989) (Lake Manzala) } & 4676.0 \\ \text { Batanouny et al. (1991): } & \\ \quad * \text { Aquatic } & 3797.0 \\ \quad * \text { Mesic } & 2660.7 \\ * \text { Saline } & 34.4 \\ \text { Serag (1991) (Salt marshes of Nile Delta) } & 1704.0 \\ \text { Serag (1996) (north west of Nile Delta) } & 4400.0\end{array}$

Heneidy \& Bidak (1996) (salin depressions) of the western Mediterranean coastal region of Egypt.

The present study indicates that the common reed reached maximum aboveground phytomass $\left(1838 \mathrm{~g}\right.$ dry $\mathrm{wt} / \mathrm{m}^{2}$ ) in September 1998. However, Fiala (1976) found that the above -ground phytomass of Phragmites increased rapidly in rhizome to aerial portions of the plant, resulting in nearly complete canopy development by early summer. After long observation of various animals, which graze on the canal and drain banks during the year, it is noticed that they are composed of cows, sheep, goats and donkies. This agrees with Heneidy \& Bidak (1996), who reported that Phragmites australis is highly palatable and is grazed by camels with some mixed flocks of sheep and goats especially on margin of saline depression habitat of the western Mediterranean Coastal region of Egypt.

In August, the phytomass of the aboveground portion of common reed is at its annual maximum in Sweden (Björndhl 1983). Since losses through grazing and premature shoot death are small in most reed stands during summer (Granéli 1989), one would expect aboveground phytomass to be close to aboveground production. However, one has to take into account that part of the shoot biomass is derived from rhizome storage products (Granéli et al. 1983), and that carbohydrates are transported downwards for the refilling of existing rhizomes and the formation of new rhizomes already starting in July (Schierup 1978).

The forage value of a consumed plant is the result of: stage of maturity, edaphic influences, plant species, climate, animal class and range condition (Le Houérou 1980). In the present study data on the voluntary intake is not available, hence the forage value is evaluated according to the chemical constituents of the plant. The nutritive value of any forage is dependent upon its content of energy- producing nutrients as well as its content 
of nutrients essential to the body. The comparison between the nutrient contents of the common reed in the present study and the range vegetation in other related studies (Table 5) might evaluate their nutrient status as forage.

Table 5. Comparison between some nutrient contents of Phragmites australis in the present study and other related studies.

\begin{tabular}{|c|c|c|c|c|c|c|}
\hline $\begin{array}{c}\text { Variable } \\
(\%)\end{array}$ & $\begin{array}{c}\text { Present } \\
\text { study }\end{array}$ & $\begin{array}{c}\text { El-Beheiry \& } \\
\text { El-Kady (1998) }\end{array}$ & $\begin{array}{c}\text { Shaltout \& } \\
\text { El-Beheiry (1997) }\end{array}$ & \multicolumn{3}{|c|}{ Batanouny et al. (1991) } \\
\cline { 5 - 7 } & 1.46 & 0.10 & 2.90 & Aquatic & Mesic & Saline \\
\hline $\mathrm{N}$ & 1.46 & 0.13 & - & - & - \\
\hline $\mathrm{P}$ & 0.12 & 0.65 & 2.60 & 0.30 & - & - \\
\hline $\mathrm{K}$ & 3.16 & 1.60 & 0.35 & 0.05 & 0.41 & 0.36 \\
\hline $\mathrm{Ca}$ & 1.65 & 0.73 & 0.65 & 0.31 & 0.06 & 0.05 \\
\hline $\mathrm{Mg}$ & 1.56 & 1.19 & 3.50 & & & \\
\hline $\mathrm{Na}$ & 1.76 & 1.96 & &
\end{tabular}

The seasonal changes in the nutrient concentrations of Phragmites showed some differences. For instance, the $\mathrm{Na}, \mathrm{K}$ and $\mathrm{Ca}$ concentrations reached a peak in winter. Similar results are reported by Mason \& Bryant (1974). Seasonal changes in the nutrient contents of reed swamp plants have been studied by Boyed (1970) for Typha latifolia and Scirpus americanus, by Bayly \& O’Neill (1972) for Typha glauca and by Kvet (1973) for Phragmites australis. Many differences in pattern can be detected. Sodium showed a midseason peak in the three species of Typha and Scirpus, but a September peak in Phragmites from Alderfess, and an early season peak in Phragmites in Czechoslovakia (Kvet 1973). Potassium reached a mid-season peak in Typha glauca, but fell steadily through the season in the other species. Magnessium levels were fairly steady through the season in T. glauca, T. angastifolia and Phragmites australis, decreased steadily in $T$. latifolia and increased steadily in Scirpus americanus. As pointed out by Boyed (1970), such differences occur in species growing under apparently the same nutrient conditions and must be due to interspecific variation in nutrient accumulation. Different stands of aquatic macrophytes show markedly different nutrient concentrations (Boyed \& Hess 1970). In the present study, seasonal variations in nutrients of the dead parts were found and along the drains have most of the highest nutrients. Towards senescence, the nutrients accumulated in the shoots can either be withdrawn into the rhizome or can be leached out of the shoots. The rhizome accounts for $55-60 \%$ on average of the total peak standing crop of Phragmites (Burian 1971; Fiala 1971; Kvet 1971), so that a possible increase of 40$45 \%$ of nutrients in the rhizome in autumn could occur. In Egypt, Serag (1996) reported that the ratio between belowground and aboveground phytomass was $0.25 \%$.

Ministry of Agriculture, Fisheries and Food in England (Anonymous, 1975) reports that minimum protein in the animal diet ranges between $6-12 \%$ depending on the animal species. NRC (1985) indicates that sheep are known to require $8.9 \%$ protein for maintenance. In the study area, average annual protein content is about $4.58 \%$ is far too low than the proper level. The living parts have $6.65 \%$, in the average, and this approaches the minimal requirements for the animal diet, while it was $2.33 \%$ for the dead parts, in the average, which is far too low than the proper level. With protein deficient diet, the metabolism of the rumen microbiota may be depressed by a deficiency in rumen nitrogen; this limitation will retard the rate of removal of organic matter from the rumen, which in turn, may reduce intake (Wetson 1971). Also, low protein levels will affect the 
wool growth, which is determined by protein absorbed in the intestine, which in turn depends on ingested nitrogen sources (Michelk \& Saville 1979).

Ash content in the present study attained about $21.56 \%$ on the annual average as compared with $11.7 \%$ in the aquatic habitat, $9.7 \%$ in the mesic habitat and $18.9 \%$ in the saline habitat as reported by Batanouny et al. (1991) and $18.9 \%$ in the saline depression habitat as mentioned by Heneidy \& Bidak (1996). The importance of lipids (ether extract) to plants, in terms of structure and use in metabolism, is well known. However, Chapin et al. (1986) indicated that lipids are clearly unimportant as an energy source in some plants. In the present study the value of $\mathrm{EE}$ (1.75\% in the annual average) is too low as compared with $10.9 \%$ in the study of Heneidy \& Bidak (1996). Total carbohydrates (NFE) attained $50.6 \%$ in the living parts and $47.9 \%$ in the dead, which are higher than the value of $33.6 \%$ reported by Heneidy \& Bidak (1996).

DCP in the study area attained on average of $1.65 \%$, which ranged between $0.8 \%$ in the dead parts and $2.9 \%$ in live parts on average. In general, straw and chaff of grasses have very low, and often zero, digestible protein content (Demarquilly \& Weiss 1970). Using the scale suggested by Boudet \& Rivière (1968), living parts of Phragmites australis in the study area considered as fair forage, but dead parts of the plant are poor. In the present study, gross energy was $4020 \mathrm{Kcal} / \mathrm{kg} \mathrm{DM}$ in the annual average. Heneidy \& Bidak (1996) recorded $4240 \mathrm{Kcal} / \mathrm{kg}$ DM, Van Epps et al. (1982) recorded a range of 3680 and $4880 \mathrm{Kcal} / \mathrm{kg}$ DM and EL-Beheiry \& EL-Kady (1998) for Tamarix species in Egypt recorded a range of 4560 and $3870 \mathrm{Kcal} / \mathrm{kg}$.

TDN is only an approximate measure of the food energy available to animal after the digestion losses have been deducted (Lofgreen 1951). Crampton et al. (1957) reported that caloric value of TDN is close to $4500 \mathrm{Kcal} / \mathrm{kg}$ TDN. In the present study, annual average TDN is about 59\% DM of the plant. In comparison, Heneidy \& Bidak (1996) recorded that TDN average of Phragmites australis in saline depression (68.79\%), ElBeheiry \& El-Kady (1998) reported that TDN for Tamarix species in Egypt as 50\%, Abdel-Razik et al. (1988) reported annual range of 66-75\% in the Mediterranean coastal region of Egypt, Soliman \& El-Shazly (1978) calculated values for Egyptian clover (56\%), barley (64\%) and (68). The annual average of ME was $1922.5 \mathrm{Kcal} / \mathrm{kg}$, in the present study, as compared with $2620 \mathrm{Kcal} / \mathrm{kg}$ by Heneidy \& Bidak (1996). Comparing NE in the present study with Boudet \& Rivière (1968) forage quality table according to its value of net energy $(0.96 \mathrm{Mcal} / \mathrm{kg}$, in annual average), Phragmites is ranked a poor quality as forage plant $(\mathrm{NE}<3.1)$.

\section{Acknowledgements}

The author is deeply indebted to Professor K. H. Shaltout, Ecological Research Unit (ERU), Faculty of Science, Botany Department, Tanta University, for revising the manuscript; Miss Thanaa El-Komi for her help in the field, laboratory and data analysis.

\section{References}

Abdel-Razik M., Ayyad, M.A.\& Heneidy, S,Z. 1988. Preference of grazing mammals for forge species and their nutritive value in the Mediterranean desert ecosystem (Egypt). Journal of Arid Environments, 15: 297-305. 
Abo Ziada M.E. 1987. Studies on the macrophytes in Egypt. I. Phragmites australis (Cav.) Trin. Ex. Spp. Altissimum (Denth.) Clyton. Mansoura Science Bulletin, 14: 169-187.

Abu Al-Izz M.S. 1971. Land Forms of Egypt. The American Univ. in Cairo Press. Dar AL-Maaref, Cairo, $281 \mathrm{pp}$.

Allen W. G., Grimshaw H.M., Parkinson J.A. \& Quarmby C. 1974. Chemical Analysis of Ecological Materials. Oxford: Blackwell Scientific Publications, 565 pp.

Anonymous 1975. Energy allowances and feeding system for ruminants. Ministry of Agriculture, Fisheries and Food. London, Her Majesty's Stationery Office. Technical Bulletin, $33 \mathrm{p}$.

Anonymous 1976. Making Aquatic Weed Useful: Some Perspectives for Developing Countries. National Academy of Science, Washington, D.C.

Batanouny K.H., Hassan A.H. \& Sawaf N.A. 1991. Ecotypes of Phragmites australis in Egypt. Proc. Intern. Conf.: Plant Growth, Drought and Salinity in the Arab Region, 97-114.

Bayly I. I. \& O'Neill T. A. 1972. Seasonal ionic fluctuations in a Typha glauca community. Ecology, 53:714-9.

Björk S. 1967. Ecological investigation of Phragmites communis. Studies in theoretic and applied limnology. Folia Limnologica Scandinavica, 14:1-248.

Boar R.R. 1996. Temporal variations in the nitrogen content of Phragmites australis (Cav.) Trin. ex. Steud. From a shallow fertile lake. Aquatic Botany, 55:171181.

Boudet G. \& Rivière R. 1968. Emploi partique des analyses fourragères pour l'appréciation des pâturages tropicaux: Rev. Elev. Méd-Vét. Pays Trop. 21(2):227-266.

Boulos L. 1995. Flora of Egypt Checklist. Al-Hadara Publishing, Cairo.

Boyed C.E. 1970. Production, mineral accumulation and pigment concentrations in Typha latifolia and Scirpus americanus. Ecology, 51: 285-90.

\& Hess L.W. 1970. Factors influencing shoot production and mineral nutrient levels in Typha latifolia. Ecology, 51: 296-300

Brix H. \& Schierup H.H. 1989. The use of aquatic macrophytes in water pollution control. Ambio, 18: 100-107.

Burian K. 1971. Primary production, carbon dioxide exchange and transpiration in Phragmites communis Trin. on the Lake Neusiedler See, Austria. Hidrobiologion, 12: 203-18.

Champan V.J. (ed.) 1960. Salt Marshes and Salt Deserts of the World. Interscience Publishers Inc., New York.

Chapin F.S., Mckendrick J.D. \& Johnson D.A. 1986. Seasonal changes in carbon fractions in Alaskan tundra plants of differing growth form: implication for herbivory. Journal of Ecology, 74: 707-731.

Demarquilly C. \& Weiss P. 1970. Tableau de la valeur alimantaire des fourrages. Et no. 42, Versailles, INRA-SEI.

Edany T.Y. \& Rezk M.R. 1981. Ecology of Phragmites australis (Cav.) Trin. Ex. Steud. In Shatt Al-Arab, Iraq. II: Reed growth as affected by the chemical composition of its beds. Polskie Archiwum Hydrobiologii, 28 (1): 19-31.

El-Beheiry M.H. \& EL-Kady H.F. 1998. Nutritive value of two Tamarix species in Egypt. Journal of Arid Environments, 38: 529-539. 
El-Gabaly M.M., Gewaifel I.M., Hassan M.M. \& Rozanov B.G. 1969. Soils and soil regions of U.A.R., Institute of Land Reclamation Research. Bulletin, 21.

Fiala K. 1971. Seasonal changes in the growth of clones of Typha latifolia in natural conditions. Folia geobt. Phytotax., 6: 255-70.

1976. Underground organs of Phragmites communis, their growth, biomass and net production. Folia Geobotanica and phytotaxonomica, 11: 225-259.

Garret W.N. 1980. Energy utilization of growing cattels as determined in seventy-two comparative slaughter expriments. P. 3 in: Energy Metabolism, L.E. Mount, (ed.) EAAP Publ. No.26. London: Butterworths.

Geranéli W. 1983. Biomass response after nutrient addition to stands of reed, Phragmites australis. Verh. Internat. Verein. Limnol., Stuttgart, 22: 2965-2961. 1989. Influence of standing litter on shoot production in reed, Phragmites australis (Cav.) Trin. ex. Steudel. Aquat. Bot., Amsterdam, 35: 99-109. 1984. Reed Phragmites australis (cav.) Trin. Ex. Steudel as an energy source in Sweden. Biomass, 4: 183-208

Gesberg R.M., Elkins B.V., Lyon S.R. \& Goldman C.R. 1986. Role of aquatic plants in waste water treatment by artificial wetlands. Water Research, 20: 283-268.

Haslam S.M. 1965. Ecological studies in the Breck Fens. I. Vegetation in relation to habitat. Journal of Ecology, 53: 599-619.

Heneidy S.Z. \& Bidak L.M. 1996. Halophytes as a forage source in the western Mediterranean coastal region of Egypt. Desert Inst. Bull., Egypt., 46(2): 261283.

Holm L.G., Plucknett D.L., Panch J.V. \& Herberger J.P. 1977. The World's Worst Weeds, Distribution and Biology. The University Press of Hawaii, Honolulu, 609 pp.

Khedr A.E. 1989. Ecological studies on Lake Manzala. M.Sc. Thesis, Bot. Dept., Fac. Sc., Mansoura Univ. Egypt.

König F. 1969. Galactolipide in Blättern und chloroplasten. Staatsexamenarbeit, Köln.

Kvet J. 1971. Growth analysis approachs to the production ecology of reedswamp plant communities. Hidrobiologia, 12: 15-40.

1973. Mineral nutrients in shoots of reed (Phragmites communis Trin.). Polskie Archwm hydrobiol., 20: 137-47.

Le Houèrou H.N. 1980. Chemical composition and nutritive value of browse in tropical West Africa. In: Le Houèrou, H.N. (ed.), Browse in Africa. Addis Ababa, pp. 261-289. ILCA. 491p.

Lofgreen G.P. 1951. The uses of digestible energy in evaluation of feeds. Journal of Animal Science, 10: 344-351.

Mason C.F. \& Bryant R.J. 1974. The structure and diversity of the animal communities in a broad land reed swamp. J. Zool. Land, 172: 289-302.

May E., Butler J.E., Ford M.G., Ashworth R., William J. \& Bahgat M.M. 1990. Chemical and microbiological processes in gravel-bed hydrophonic (GBH) systems for new age treament. Pages 33-40 in Cooper, P.F. \& Findlater, B.C. (ed.), Proceedings Conf. Constructed Wetlands in Water Pollution Control, Pergamon Press, Oxford.

NRC 1985. Nutrient Requirements of Domestic Animals. Nutrient requirement of sheep. ( $6^{\text {th }}$ Edn.) Research Council Pamphelets No. 5 Washington, DC, National Academy of Science, 663pp.

Ölberg K. 1956. Factors affecting the nutritive value of range forage. Journal of Range Mangement, 9: 220-225. 
Riemer D.N. 1976. Long-term effects of Glyphosate applications to Phragmites. J. Aquat. Plant Manage., 14: 39-43.

Rivière R. 1977. 'Mannual d'alimentation des ruminants domestiques en milieu tropical'. Manuels et précis d'élevage, no 9, Maison- Alfort, IEMVT.

SAS 1985. SAS/STAT User's Guide. SAS Institute Inc., Cary. 956pp.

Scharrer H. \& Kürschner H. 1967. Handbuch der Lebensmittelchemie. Band II/2, Springer-Verlag, Berlin.

Schierup H.H. 1978. Biomass and primary production in a Phragmites communis Trin. swamp in North Jutland, Denmark. Verh. Internat. Verein. Limnol., Stuttgart, 20: 94-99.

Sculthorp C. 1967. The Biology of Vascular Plants. Edward Arnold, London. 610pp.

Serag M.S. 1991. Studies on the ecology and control of aquatic and canal bank weeds of the Nile Delta, Egypt. Ph.D. Thesis, Bot. Dept., Fac. Sc., Mansoura Univ. Egypt.

Serag M.S. 1996. Ecological and biomass of Pharagmites australis (Cav.) Trin. Ex. Steud. In the north-eastern region of the Nile Delta, Egypt. Ecoscience, 3 (4): 473-482.

Shaltout K.H. \& El-Sheikh M.A. 1993. Vegtation-environmen relations along the water courses in the Nile Delta region. Journal of Vegetation Science, 4: 567-570.

Shata A. \& El-Fayoumi I. 1970. Remarks on the regional geological structure of the Nile Delta. In: Hydrogeology of Deltas Proc. of the Bucharest Symposium (1961) 1: 189-197. JASH/AIHS, UNESCO, Paris.

Täckholm V. 1974. Students'Flora of Egypt. Cairo University Press, Cairo.

UNESCO 1977. Map of the world distribution of arid regions. MAB, Technical Notes 7, Paris.

Van Epps G.A., Barker J.R. \& Mckell C.M. 1982. Energy biomass from large rangeland shrubs of the intermountain United States. Journal of Range Management, 35: $22-25$.

Viljoen L. 1976. Uses of Phragmites australis. Weidingsveren. S. Afr., 11: 19-22.

Westen R.H. 1971. Factors limiting the intake of feed by sheep. 5. Feed intake and the productivity performance of the ruminant lamb fed on concentrate diets based on wheat. Australian J. of Agriculture Research, 25: 349-362.

Williams J. Bahgat, M.M. May, E. Ford, M. \& Butler J. 1994. The removal of pathogenic microorganism during sewage treatment in gravel bed hydroponic constructed wetlands. Pages 200-209 in : Proceedings of a Conf. On Wetland Systems for Water Pollution Control, IAWQ, Gunagzhou.

Zahran M.A. \& Willis A.J. (ed.) 1992. The Vegetation of Egypt. Chapman and Hall, London. 